\title{
An examination of some instructional practices in selected rural secondary schools
}

\author{
Mapula G Ngoepe \\ University of South Africa, Department of Mathematics Education \\ ngoepmg@unisa.ac.za
}

\section{Doi:10.5901/mjss.2014.v5n9p464}

\section{Abstract}

\begin{abstract}
South African learners continue to achieve poorly in mathematics in comparison to other countries. Although there are numerous factors influencing learner achievement in South Africa, the instructional practices that mathematics teachers use have a profound influence on students' learning and achievement. One fruifful endeavour that has been used by researchers to improve students' learning of mathematics was to investigate the state of instruction to propose alternative ways of teaching. This article examines teaching practices that were observed in three disadvantaged secondary schools in 12 lessons of eight mathematics teachers in grades 10 to 12. The results revealed that predominant instructional practices used by the teachers included homework, unproductive questioning, chorus responses, group work discussions, textbook use, teacher talk, copying and writing down answers. The findings will shed light on the kind of intervention programmes to be planned for the teachers to improve teaching and learner achievement.
\end{abstract}

Keywords: secondary school; mathematics teaching; effective mathematics teaching; mathematics practices; disadvantaged schools

\section{Introduction}

The question of what constitutes effective instructional practice in mathematics has been on the research agenda for decades. According to Askew, Brown, Rhodes, Johnson, \& William (1997) 'there is not a neat set of things that effective teachers do and consequently one cannot become an effective teacher of mathematics simply by doing certain things and avoiding doing others (Askew et al., 1997, p57). Watson and De Geest (2005) claim that 'it is somewhat the principles or beliefs that underlie particular practices that determine their effectiveness' (Askew et al. p57).

The principles of effective teaching of mathematics have been identified by researchers such as Muir (2008a); Askew et al. (1997) and Clarke et al. (2002) as encompassing: making connections, challenging learners to think, teaching for conceptual understanding, purposeful discussions, focus on mathematics and positive attitudes. Van de Walle, Karp \& By-Williams (2014) describe an effective teacher as the teacher who possesses mathematical knowledge and strategies to present mathematics content, also considering beliefs about what it means to know and do mathematics and about how students make sense of mathematics. Possessing this kind of knowledge will affect how instruction is approached. The National Council of Teachers of Mathematics (NCTM) (2009) is of the view that effective mathematics teachers maximize learning by using instructional practices that focus on promoting mathematical thinking and reasoning (NCTM, 2000).

\section{effective mathematics teaching requires understanding what students know and need to learn and then challenging and supporting them to learn well ( NCTM, 2000, p16).}

Furthermore, what students learn about mathematics depends almost entirely on the experiences that the teachers offer every day in the classroom. Subsequently, an examination of the state of mathematics instruction in disadvantaged secondary schools became essential to try and identify instructional practices used for the purpose of designing intervention that could improve teaching and learner achievement.

\section{Literature Review}

\subsection{Nature of mathematics instruction}

Researchers such as Brophy \& Good (1996) and Floden (2001) have long tried to characterise the nature of the mathematics instruction that maximises student learning opportunities. Other researchers, considered the kinds of 
pedagogical practices that contribute to desired student outcomes (Anthony and Walshaw, 2007; National Mathematics Advisory panel, 2008; Hiebert and Grouws, 2007). In my view, the nature of instruction need to include exposition by the teacher, discussion between the teacher and the learner and between learners themselves; appropriate practical work; consolidation of practice of fundamental skills and routines; problem solving, including the application of Mathematics to everyday situations and investigational work (Cockcroft, 1982, Para. 243).

\subsection{Effective mathematics teaching}

Early researchers in teacher effectiveness of mathematics focused on teacher knowledge of mathematics (Thompson, 2004), teacher beliefs about mathematics, mathematics learning and mathematics instruction (Beswick, 2007; Wilkins, 2008). For instance, Anthony and Walshaw (2009) developed a set of 10 principles that underpin the kinds of pedagogical approaches that were found to assist in developing teachers' mathematical capability and disposition. The principles were based on recognition that classroom teaching is complex. It is neither static nor linear. Somewhat, it is 'nested within an evolving network involving the school, the wider education system, and the home and local community' (p.149). These principles of effective pedagogy of mathematics are:

- teacher knowledge and learning,

- an ethic of care;

- arranging for learning;

- building on students' thinking;

- mathematical communication;

- mathematical language;

- assessment for learning;

- worthwhile mathematical tasks;

- making connections, tools and representation

To contribute towards effective mathematics teaching, researchers such as Kilpatrick, Swafford and Findell (2001) established and described what they called five strands of mathematics proficiency which were further refined by Watson and Sullivan (2008). These five strands are conceptual, procedural, strategic competence, adaptive reasoning and productive disposition (Watson and Sullivan (2008). In my opinion, all the five mathematical actions are important in any mathematics classroom and contribute to a balanced curriculum. Rural mathematics would need to be supported in reflecting and implementing these strands in their instruction.

\subsection{The role of the teacher in promoting effective teaching practices in a mathematics classroom}

In South Africa, the National Policy framework for teacher education and development (National Department of Education 2007) provides a guideline of an effective teacher as expressed in the Norms and Standards for Educators (NDE, 1997) which set out seven roles of the teacher, these being specialist in mathematics teaching and learning, assessment, curriculum development, leader, administrator and manager, scholar and lifelong learner and a professional who plays a community, citizenship and pastoral role. The document further recommends the need for continuing professional development for teachers in both conceptual, content, and pedagogical knowledge for effective teaching as well as the teachers' willingness and ability to reflect on practice and learn from the learners' own experience of being taught. Integration of these aspects is important for the teacher to apply 'conceptual knowledge -in- practice' (National department of education 2007, p16). In order to provide high quality mathematics education, NCTM (2000) suggests that teachers must:

a. Have a deep understanding of mathematics,

b. Understand how students learn mathematics, including a keen awareness of the individual mathematical development of their own students and common misconceptions,

c. Select meaningful instructional tasks and generalizable strategies that will enhance learning and

d. Know that their actions are what encourage students to think, question, solve problems and discuss their ideas, strategies and solutions (p18).

Scott, Terence, Lane and Holly (2001) in Van de Walle, Karp \& By-Williams (2014), perceive the role of a qualified teacher of mathematics as incorporating high-quality curriculum and challenging standards for achievement, commitment to teaching the curriculum as laid out by education ministries, using multiple representations such as manipulatives, visual models and symbols, monitoring progress to identify struggling students, using flexible student grouping, fostering 
active student involvement and communicating high expectations for all students. Rosenshine and Stevens (1986) acknowledge that researchers have found that effective teachers:

- Begin a lesson with a short review of previous, prerequisite learning.

- Give a short statement of goals.

- Present new material in small steps, with student practice after each step.

- Give clear and detailed instruction and explanations.

- Provide a high level of active practice for all students.

- Ask a large number of questions, check for student understanding, and obtain responses from all students.

- Guide students during initial practice.

- Provide systematic feedback and corrections.

- Provide explicit instruction and practice for seatwork exercises and where necessary, monitor students during seatwork.

Rural settings mathematics teachers should provide students opportunities to engage in mathematical inquiry during instruction as proposed by Rosenshine and Stevens (1986). I am of the view that this sequenced structure is more likely to enhance the flow of a lesson focusing on developing procedural fluency than the mere setting of examples for practice. The structure also has the potential to enhance conceptual understanding and develop some adaptive reasoning as proposed by Kilpatrick, Swafford and Findell (2001).

\section{Research Methodology}

This study used an interpretive qualitative research design. Interpretive studies can provide detailed information about very small samples (Erickson, 1986). Because this research was concerned about the details of teachers' practices in mathematics classrooms, Yin (2003 suggested that case studies are the preferred research strategy when the investigator has little control over events and when the focus is on contemporary phenomenon within some real life context.

For this research, a case study entailed descriptions of the individual teacher's instructional practices. Eight teachers in three schools formed the purposive sample. Pseudonyms were used to protect the teachers' identity. The Grade 10 to 12 lessons of the teachers were observed and video-recoded. Researcher field notes were taken (Patton, 2002). The video record was used to validate the observations (MacMillan \& Schumacher, 2010). The lessons were analysed with focus on the instructional practices teachers used. Themes were allowed to emerge (Patton, 2002)

\section{Findings}

The themes which emerged from the findings include homework, unproductive questioning, chorus responses, group work discussions, textbook use, teacher talk, copying, writing down answers. They are discussed as follows:

\subsection{Homework}

Homework seemed to be one of the most important teaching strategies used by the teachers. In almost all the observed analysed lessons, every lesson started with homework correction which was carried out in two ways, either by inviting learners to come to the chalkboard and work out problems or the teacher simply working out these problems on the chalkboard. As the analysis revealed, almost all the learners who were called forth to work out problems on the chalkboard were not able to complete the problem. Subsequently, as observed, the teacher would take over and work out these problems without asking the learners about their specific difficulties or pointing to the difficult area. The learners' attempts were simply wiped out from the chalkboard without asking what it was they could not do.

In other instances, without even asking learners which difficulties they encountered when doing the homework problems or without saying anything, the teacher would start writing solutions to these homework problems on the chalkboard and the learners would copy down the answers.

In the light of this discussion on homework, since homework plays such a major role in the learning and teaching of mathematics in these schools, this is an aspect that needs to be investigated on how best to handle this activity to better impact on student learning. 


\title{
4.2 Unproductive questioning
}

An example of one of the lessons where unproductive questioning was observed shows that the teacher spent six minutes asking questions that were unproductive when leading learners towards recalling the quadratic formula, for example,

\begin{abstract}
Mr Timba said: "I am going to ask each one of you. Have you forgotten it? Don't you know? (The teacher pointed a chalk at the board for about one minute waiting for learners to respond so that he could write the formula. You wrote it in the assignment. Have you forgotten it? Let me hear you. Do you also know it? Have you also forgotten?"(Pointing at a learner).
\end{abstract}

These questions do not lead to thought-provoking processes. They did not encourage problem solving strategies as suggested by Polya (1973) that " ... if you solve it by your own means, you may experience the tension and enjoy the triumph of discovery"( p.v).

\subsection{Chorus responses}

Chorus responses characterised almost all of the observed lessons. It was common to have teachers pose questions and answer them alone or together with the learners. When the teacher posed a question, all the learners answered, or some learners answered. When this happened, it was difficult to know whether all the learners had the same level of understanding of the subject matter or whether they followed the lesson without reflecting upon what was being said. In all the analysed lessons, teachers did not probe the learners to respond individually.

Similarly, a study on language practices in mathematics classrooms in South Africa revealed that chorusing featured strongly in secondary schools as compared to primary schools (Setati, 1998). Setati speculated that though it was not teacher initiated, it seemed to be a means of assuring the teacher that everyone still followed instruction. Based on my observations in these lessons, although chorus responses did not reveal learners' understanding of the subject matter, they were used as a way of assuring the teacher that learners are paying attention to instruction. Furthermore, the teachers seemed to expect students to respond that way since they did not attempt to probe students to respond individually.

\subsection{Group-work discussions}

Several classes had learners seated in groups although during class teaching these groupings did not seem to be leading to intellectual debate. For example, in Ms Makola's lesson, each of the groups, except for one which did not have a calculator at all, had only one calculator between them. The group discussions seemed to be more on learners seeking help on how to operate the calculators and less on the mathematical ideas under discussion. In Mr Nare's lesson, for example, the learners had different calculators and were seen moving from one group to another, trying to figure out how they could solve problems with calculators that they borrowed from friends in another class.

\subsection{The textbook}

In almost all the observed lessons, learners normally did not have textbooks with them during the lesson. Consequently, the teacher spent much time writing problems on the chalkboard for learners to copy and those problems could easily be copied wrongly. Concerning the homework in the absence of the textbook, it was also revealed that one teacher, Mr. Nare, would read out problems for learners. As I was taking down field notes, I was struggling to catch up with the writing of the problems since they were read aloud only once. In some instances, where the textbooks provided by the school were to be shared, it was difficult for learners who shared the book to do the homework.

A common phenomenon was for the learners to frequently turn the pages of their notebooks. I suppose this was done to check how previous work was done or to check for a formula since their notebooks were the main point of reference in the absence of the textbook in class. Learners tended to write notes given by the teachers into the back of their notebooks. This turning of pages might also be a result of searching for examples on how the problems were supposed to be solved. 


\subsection{Teacher talk}

In almost all the analysed lessons, the teacher was the one talking all or most of the time. Students normally listened attentively to the teacher and seemed to depend much on the spoken word of the teachers because they did not bring their textbooks during instructional periods. It was also revealed that the teachers did not give time for learners to complete their chalkboard problems. Further, the teachers did not guide learners to think through what they wrote in order to help and finish solving the problem.

\subsection{Copying}

One common characteristic was for learners to copy worked out exercises from the chalkboard. There was no time for reflection when learners were copying most of the time. These practices have been observed in Black mathematics and science classrooms in South Africa (Jita, 2002). However, it seems that in these three rural schools, copying might be a result of learners not being in possession of the textbook in class.

\subsection{Writing down answers}

The idea of giving answers prior to learners actually working out these problems has been evident in some of the lessons. This might be a good way of encouraging learners to work out solutions independently, but as seen in the lessons this approach did not end up in fruitful results. The teacher ended up solving the problems since the students seemed not to know how to work them out. This approach to problem solution could be linked to the absence of the textbook in the classroom to which learners could refer.

\section{Conclusion}

The aim of this article was to examine the instructional practices used by some rural mathematics teachers. The literature revealed what researchers and policy documents acknowledged as effective mathematics practices. Looking at the findings and what the literature says about effective teachers and instructional practices no wonder why South Africa and in particular, disadvantaged communities continue to perform poorly. The practices as used are unique to these schools. However they are not in par with effective mathematics practices as discussed in the literature

Although the sample was small, it shed light on instructional practices. Future research needs to focus on how to help the teachers to use effective strategies of dealing with homework, asking productive questions, chorus responses, conducting group work discussions, textbook use, teacher talk and writing in mathematics classes.

\section{References}

Askew, M., Brown, M. Rhodes, V., Johnson, D., \& William, D. (1997). Effective teachers of numeracy. London: School of Education, King's college.

Anthony, G. \& Walshaw, M. (2009). Characteristics of Effective Teaching of Mathematics: A View from the West. Journal of Mathematics Education 2(2), 147-164.

Beswick, K. (2007). Teachers' beliefs that matter in secondary mathematics classrooms. Educational studies in mathematics, 65(1), 95120.

Brophy, J. E., \& Good, T. L. (1996). Teacher behavior and student achievement. In M. C. Wittrock (Ed.), Handbook of research on teaching (3rd ed., pp. 328-375). New York: Macmillan.

Clarke, D., Cheeseman, J.,Gervasoni,A.,Gronn, D., Horne, M., et al. (2002). Early numeracy research project final report. Melbourne: Mathematics Teaching and learning centre, Australian catholic University.

The Cockcroft Report (1982). Mathematics counts: Report of the Committee of Inquiry into the teaching of mathematics in schools under the chairmanship of Dr WH Cockcroft. London: Her Majesty's Stationery Office.

Erickson, F. (1986). Qualitative methods in research on teaching. In M. C.

Wittrock (Ed.), Handbook of research on teaching (3rd ed., pp. 119 -160). New York, N.Y: Macmillan.

Floden, R. E. (2001). Research on effects of teaching: A continuing model for research on teaching. In V. Richardson (Ed.), Handbook of research on teaching (4th ed., pp. 3-16). Washington, DC: American Educational Research Association.

Hiebert, J.,\& Grouws, D.A. ( 2007). The effects of classroom mathematics teaching on students learning In F.K. Lester Jr. (Ed.), Second Handbook of research on mathematics teaching and learning (Vol.1, pp.371-404). Charlotte, NC: Information Age Publishing.

Jita, L. (2002). A Transformative practice in science education: What is it? What does it look like? Images form South African classrooms. Paper presented at the Southern African Association for Research in Mathematics, Science and Technology 
Education, Durban.

Kilpatrick, J., Swafford, J., \& Findell, B.(Eds.). (2001). Adding it up: Helping children learn Mathematics. Washington, DC: National Academy Press.

MacMillan, J.H., \& Schumacher,S. ( 2010). Research in Education. Evidence-Based Inquiry. Pearson Education, Inc, Upper Saddle River, New Jersey.

Muir, T. (2008a). Principles of practice and teacher actions: Influence on effective teaching of numeracy. Mathematics Education Research Journal, 20(3)78-101.

National Mathematics Advisory Panel. (2008) Washington, DC: U.S.

National department of education (2007). Norms and standards for Educators (NDE 1997). Pretoria: Department of Education.

Department of Education (1997). Curriculum 2005: Lifelong learning for the 21st Century. Pretoria: Department of Education.

National Council of Teachers of Mathematics (NCTM) (2000). Principles and Standards for School Mathematics, Reston, VA: Author

Patton, M. Q. (1990). Qualitative evaluation and research methods. London: Sage Publication.

Polya, G. (1973). How to solve it. New Jersey: Priceton University Press.

Rosenshine, B. , \& Stevens, R. (1986). Teaching functions. In M. C. Whittrock(Ed.), Handbook of research on teaching (3rd ed., pp. $376-$ 391). New York: Macmillan.Setati, M. (1998). Languages practices in mathematics classrooms: Focus on code switching, chanting and chorusing. Paper presented at the Southern African Association for Research in Mathematics and Science Education, Pretoria.

Thompson, A. G. (2004). The relationship of teachers' conceptions of mathematics and mathematics teaching to instructional practice. In B. Allen \& S. J. Wilder (Eds.), Mathematics education: Exploring the culture of learning (pp. 175-194). London: Routledge Falmer.

Yin, R.K. (2009). Case study techniques: Design and methods (2nd ed.). Newbury Park, CA: Sage

Van de Walle, JA, Karp K. S. Bay-Wiliams J.M. (2014). Elementary and middle school Mathematics teaching developmentally, 8th Ed, Boston: Pearson

Watson, A, \& Sullivan, P. (2008). Teachers learning about tasks and lessons. In D. Tirosh, D. \& Wood, T. (Eds) Tools and resources in mathematics teacher education (pp. 109-135). Sense Publishers: Rotterdam

Watson, A. \& De Geest, E. (2005). Principled teaching for deep progress: Improving mathematical learning beyond methods and materials. Educational studies in mathematics, 58(2), 209-234.

Wilkins JLM (2008). The relationship among elementary teachers' content knowledge, attitudes, beliefs, and practices. J. Math. Teach. Educ., 11: 139-164. 